\section{Re: Tatoveringsblekk - en underkjent helsefare?}

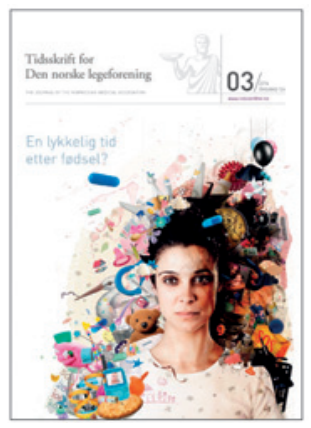

På vegne av Norsk Tattoo Union vil jeg komme med en kommentar til artikkelen i Tidsskriftet nr. 3/2014 (1).

Det er ingen hemmelighet at tatoveringsfarge tidligere har vært laget av stoffer som ikke har vært bra å dytte inn i en menneskekropp. Tatoveringsbransjen er en bransje som har vært i kraftig vekst og har hatt en enorm utvikling de siste ti årene. En bransje som vokser så raskt så fort får en rekke utfordringer, og tatoveringsfarge har vært én av disse utfordringene. Det er et stort marked for tatoveringsfarge, med en jungel av forskjellige merker. I tillegg til de anerkjente, trygge merkene sliter bransjen med piratkopier som er nærmest umulig å skille fra de originale. Disse kopifargene, som er laget kun for å tjene penger, gjennomgår ikke de samme kontroller som seriøse europeiske produsenter. I tillegg blir disse fargene brukt av personer som tatoverer hjemme på kjøkken og gutterom uten opplæring innenfor hygiene eller allergier/komplikasjoner.

Jeg er en smule overrasket over at artikkelforfatteren ikke har fått med seg at Norge 1.1. 2009 innførte en av Europas strengeste forskrifter for tatoveringsprodukter (2). For å få den nødvendige godkjenningen for å drive tatoveringsvirksomhet, skal det på hvert enkelt tatoveringsstudio utarbeides internkontrollsystemer med nedskrevne rutiner som ivaretar farene ved tatovering (komplikasjoner/allergier) og de nødvendige skritt for å ta vare på tatoveringen (etterbehandling) (3). Får man utført tatovering på et studio som har sine rutiner i orden, vil faren for å pådra seg infeksjon være langt større i tiden etter at tatoveringen er laget (groperioden) enn under selve tatoveringsprosessen. I tillegg til dette har norsk tatoveringsbransje en forskrift som pålegger oss å fortelle våre kunder om de komplikasjoner som kan oppstå ved å få utført tatovering.

Norsk Tattoo Union har et godt samarbeid med Mattilsynet om tatoveringsprodukter (farger/blekk) og med Folkehelseinstituttet om innrapportering av uønskede hendelser som omhandler tatovering. Unionen kom 9.3. 2012 med en pressemelding som omhandlet farlige stoffer i tatoveringsfarge (4).

Norsk Tattoo Union ser positivt på at den norske legestanden tar tatovering på alvor, og vi ønsker at de uttalelser som måtte komme er korrekte. Vi er Norges eneste bransjeforening for tatovering, og vi tar yrket vårt på alvor. Bruk gjerne våre nettsider og ta kontakt med oss om det er noe leger måtte lure på i fremtiden (5). Vi kan ikke like mye om hud og fagtermer som leger, men vi kan en hel masse om tatovering og de forskriftene vi er underlagt for å utføre vårt virke lovlig.

Mange av oss har selvfølgelig en god del tatoveringer, men på tross av dette er vi faktisk en gjeng med rimelig fordomsfrie og allrighte folk.

\section{Per-Erik Dahlman}

pero@norsktattoounion.org

Per-Erik Dahlman (f. 1972) er sekretær i Norsk Tattoo Union.

Ingen oppgitte interessekonflikter.

\section{Litteratur}

1. Gunnarsson GL, Eiriksdottir HB, Knapskog E et al. Tatoveringsblekk - en underkjent helsefare? Tidsskr Nor Legeforen 2014; 134: 274

2. FOR-2008-11-03-1189. Forskrift for produksjon, import og omsetning mv av tatoveringsprodukter og andre produkter til injisering i huden i kosmetisk hensikt. http://lovdata.no/dokument/SF/forskrift/2008-11-03-1189? $q=$ tatoveringsprodukter (14.2.2014).

3. FOR-1998-05-06-581. Forskrift om hygienekrav for frisør-, hudpleie-, tatoverings- og hulltakingsvirksomhet m.v. http://lovdata.no/dokument/SF/forskrift/ 1998-05-06-581?q=tatovering (14.2.2014).

4. Norsk Tattoo Union. For media. www.norsktattoounion.org/For-Media.html (14.2.2014).

5. Norsk Tattoo Union. www.norsktattoounion.org/ (14.2.2014).

\section{G.L. Gunnarsson og medarbeidere svarer:}

I artikkelen formulerer vi oss slik at diskusjonsgrunnlaget ikke begrenses. Tatoveringsfarger kontrolleres av Mattilsynet, men etter å ha sett nærmere på dagens regelverk har vi grunn til å tvile på om dette er optimalt. Regelverket ser ikke ut til å være i tråd med bransjens omfang og hvilke konsekvenser mangelfull kontroll kan få. Nåværende myndigheter har ikke oversikt over forekomsten av bivirkninger, plager og skader som forekommer på tross av en paragraf i regelverket om utøvers rapporteringsplikt (1).

Kanskje er det bedre at tatoveringsfarger kontrolleres som legemidler heller enn som matvarer? Hva kan fargene inneholde? I dag inneholder fargene alt fra kvernet skosåle til tungmetaller, med unntak av en tømmende liste av kjemikalier som de ikke skal inneholde (1). Kanskje burde det være omvendt? En tømmende liste av hva fargene kan inneholde, basert på klinisk forskning og langtidserfaringer?

Når det foregår offentlig kontroll, føler befolkningen en viss trygghet. Når røde flagg dukker opp, er det vår plikt å stille kritiske spørsmål for å ivareta optimal folkehelse. Vi stiller spørsmål ved om tatoveringsfarger kan være en underkjent helsefare. Vi mener spørsmålet er relevant dersom noen kommer til skade, og det finnes grunnlag for innskjerping av relevante aktører.

Vi etterlyser et bedre system for å kunne undersøke og holde oversikt med omfanget av tatoveringsreaksjoner og bivirkninger ved impregnering av menneskekroppen. Vi ber alle om å være kritiske til hva de setter inn i kroppen på kort og lang sikt. Uønskede hendelser bør journalføres og rapporteres videre slik at man kan danne seg et bilde av det totale omfanget av problemstillingen. I situasjonen vi beskriver i artikkelen, var ikke dette gjort (2). Hvorfor ikke? Kanskje regelverket er for stramt og straffer i stedet for å belønne ved varsling? Er det et godt regelverk, eller kan det bli bedre?

\section{Gudjon L. Gunnarsson \\ gudjonleifur@yahoo.com \\ Hulda B. Eiriksdotter \\ Erik Knapskog \\ Carsten S. Mikkelsen}

Gudjon L. Gunnarsson (f. 1973) er spesialist i plastikkirurgi. Han er overlege ved Plastikkirurgisk avdeling, Sykehuset Telemark.

Ingen oppgitte interessekonflikter.

Hulda B. Eiriksdottir (f. 1975) er lege i spesialisering i allmennmedisin og fastlege ved Sentrum legesenter i Skien.

Ingen oppgitte interessekonflikter.

Erik Knapskog (f. 1966) er fastlege ved Sentrum legesenter i Skien. Ingen oppgitte interessekonflikter.

Carsten S. Mikkelsen (f. 1968) er spesialist i hud- og veneriske sykdommer og overlege ved Brønderslev hudlegeklinikk i Danmark. Ingen oppgitte interessekonflikter.

\section{Litteratur}

1. FOR-2008-11-03-1189. Forskrift for produksjon, import og omsetning mv av tatoveringsprodukter og andre produkter til injisering i huden i kosmetisk hensikt. http://lovdata.no/dokument/SF/forskrift/2008-11-03-1189?q= tatoveringsprodukter (142.2014).

2. Gunnarsson GL, Eiriksdottir HB, Knapskog E et al. Tatoveringsblekk - en underkjent helsefare? Tidsskr Nor Legeforen 2014; 134: 274. 